\title{
Od reformy kurikula k produktivní kultuře vyučování a učení ${ }^{1}$
}

\author{
Tomáš Janík \\ Masarykova univerzita, Pedagogická fakulta, Institut výzkumu školního vzdělávání
}

Redakci zasláno 2. 7. 2013 / upravená verze obdržena 8. 10. 2013 / k uveřejnění přijato

12. 10.2013

\begin{abstract}
Abstrakt: Předložený text je pokusem o analytickou studii s programovým vyústěním. Jeho cílem je teoreticky vymezit a empiricky analyzovat „problém“ kurikulární reformy a koncipovat její vztah ke kultuře vyučování a učení. V úvodu autor zasazuje současnou českou kurikulární reformu do širšího kontextu vzdělávací transformace a zamýšlí se nad předmětem a charakterem reformy. $V$ návaznosti na to s využitím tzv. ekvalizéru governance rozebírá problém načasování reformy, a to $\mathrm{v}$ kontextu analýzy širších mechanismů fungování a ovládání školského systému. Za klíčové lze považovat autorovo tvrzení, že současná česká kurikulární reforma stěží pozvedne kvalitu výuky, nebot' její implementace vyústila v nezvladatelný formalismus. Cesta ke kvalitě výuky podle autora spočívá v podpoře produktivní kultury vyučování a učení. Realizovat změnu tudíž znamená propracovat novou - produktivní - kulturu vyučování a učení. V závěru autor předkládá argumenty pro potřebu „programu“ spočívajícího v rozvinutí kurikulární reformy do koncepce podpory škol a profesního rozvoje učitelů s ideou produktivní kultury vyučování a učení na horizontu.
\end{abstract}

Klíčová slova: edukační změna, reforma, kurikulární reforma, vzdělávací transformace, kurikulární politika, kultura vyučování a učení, profesní rozvoj učitelů

Tento text je o reformě a o reformování ve školství. Jak se lze přesvědčit na základě pohledu do odborné literatury či denního tisku, reforma je slovem širokého významu. Používá se v různých souvislostech - a mnohdy nevhodně. Nejen ve školství se za reformu nepatřičně vydávají různá jednorázová či dílčí opatření, optimalizace, příležitostné škrty apod. V odborném jazyce je naproti tomu pojem reforma používán pro označení širšího systémového zásahu, který se vyznačuje tím, že je promyšlený, plánovaný, koordinovaný a v ideálním případě též předem ověřený formou tzv. modelového experimentu.

1 Tato studie byla zpracována v rámci řešení projektu GA ČR P407/11/0262 Kvalita kurikula $a$ výuky $v$ oborech školního vzdělávání - její uveřejnění bylo tímto projektem finančně podpořeno. Autor děkuje za poskytnutou podporu. 
Jak už to tak bývá, zatímco jedni reformování propagují, nebot' v něm spatřují šanci na vyvedení z problémového stavu, jiní je bojkotují z obavy, že problémový stav se (neustálým) reformováním jen prohloubí. Není divu, že jako rozumnější se mnohdy jeví setrvat $\mathrm{v}$ klidu nebo $\mathrm{v}$ rovnoměrně zrychleném pohybu, dokud nás nějaké těleso nepřinutí tento stav změnit... $V$ přeneseném významu i toto může být ambicí reforem a reformátorů. Vyhodnotit účinnost reforem a reformování v časovém odstupu je potom úkolem analytiků (zejména historiků), jejichž texty nacházejí prostor na stránkách vědeckých, odborných i popularizačních časopisů.

Od textu pro Pedagogickou orientaci ${ }^{2}$ se právem očekává, že bude řešit nějaký relevantní problém - v daném prŕípadě např̀ ve vztahu ke kurikulární reformě. Problém je však problémem zpravidla proto, že se přesně neví, v čem spočívá. Vymezení a strukturace problému je tudíž svébytným badatelským aktem (srov. Veselý, 2011, s. 33). Vymezit problém znamená nabídnout relativně soudržnou strukturu pojmů, které jej umožní nahlédnout diferencovaně a v adekvátní hloubce ponoru. Mimo jiné o to jde v tomto textu. Více či méně o to šlo i v celé řadě dalších textů, at' již jde o přehledové, teoretické či empirické studie v časopisech (např. Maňák, 2003; Skalková, 2005; Spilková, 2005; Kratochvílová, 2007; Skalková, 2007; Straková, 2007; Urbánek \& Wernerová, 2008; Štech, 2009; Janík, Maňák, Knecht, \& Němec, 2010; Janík, Najvar, \& Solnička, 2011; Janík et al., 2011c; Štech, 2013), o diskusní př́íspěvky (např. Prášilová, 2008; Hrubý, 2011; Kuhn, 2011; Tupý, 2011; Šíp, 2013; Straková, 2013) či o výzkumně založené monografie nebo jejich části - kapitoly (Štech, 2003; Štech, 2006; Janík et al., 2010a; Janík et al., 2010b; Píšová, Kostková, \& Janík et al., 2011; Janík, Slavík, \& Najvar et al., 2011; Janík et al., 2011b; Janík et al., 2011c; Straková, 2010; Walterová, Černý, Greger, \& Chvál, 2010, s. 149-189; Dvořák, 2012; Starý, Dvořák, Greger, \& Duschinská, 2012, s. 83-89; Pol et al., 2013, s. 48-55; Tupý, 2014) z posledních deseti let. Mimo jiné díky těmto textům se daří držet závažné téma, jímž kurikulární reforma dle mého názoru je, ve veřejném diskursu o vzdělávání.

Pro autory těchto textů je či byla kurikulární reforma aktuálně žitou skutečností - je tudíž obtížné komentovat ji s žádoucím vědeckým odstupem. Při vědomí problému "distance v blízkosti“ mají autoři usilovat o to, aby ve svých textech dali znát, co jsou jejich osobní názory a postoje a co jsou

2 Text je založen na plenárním referátu, který byl autorem přednesen 21. března 2013 na 20. výroční konferenci České pedagogické společnosti na Fakultě přírodovědně-humanitní a pedagogické Technické univerzity v Liberci. 
výsledky pokud možno nestranných analýz a výzkumů. V odkazovaných textech nachází čtenář obojí a nejinak je tomu v případě tohoto textu. Ten se sice opírá o výzkumy, které autor s širším kolektivem spolupracovníků realizuje od roku 2007 do současnosti (viz výše), avšak současně chce zůstat osobní výpovědí autora, pro něhož je kurikulární reforma a její zkoumání žitou skutečností. Avizovat text jakožto osobní výpověd' znamená vyzvat čtenáře, aby nepřeceňoval to, co je v textu uvedeno. Jedná se přece jen o názor jednoho člověka, který se sice opírá a četné analýzy a výzkumy, avšak to ještě neznamená, že by předkládaná zjištění a prezentované závěry neměly být předmětem dalšího kritického přezkoumání.

$\mathrm{V}$ tomto textu se pokouším teoreticky vymezit a empiricky analyzovat „problém“ kurikulární reformy a koncipovat její vztah ke kultuře vyučování a učení. V úvodu zasazuji současnou českou kurikulární reformu do kontextu vzdělávací transformace, zamýšlím se nad jejím předmětem a charakterem a v daných souvislostech komentuji její příběh. Následně rozebírám problém načasování reformy, a to v kontextu analýzy širších mechanismů fungování a ovládání školského systému - využívám k tomu tzv. ekvalizér governance. Na tomto základě předkládám tvrzení, že současná kurikulární reforma stěží pozvedne kvalitu výuky, nebot' její implementace vyústila v nezvladatelný formalismus. Kvalitu výuky považuji za horizont snah o reformu školy. Argumentuji, že cesta ke kvalitě výuky spočívá $\mathrm{v}$ podpoře produktivní kultury vyučování a učení přímo ve školních třídách. Uvádím, že je zapotřebí připravit a realizovat „program“ spočívající v rozvinutí kurikulární reformy do koncepce podpory škol a profesního rozvoje učitelů tak, aby se směřovalo k produktivní kultuře vyučování a učení.

\section{$1 \quad$ Kurikulární reforma}

\subsection{Kdy(ž) je změna reformou}

$\mathrm{S}$ cílem uvedení do problematiky nahlédněme nejdříve pojem reforma $\mathrm{z}$ teoretického odstupu. Jeho nadřazeným pojmem je pojem změna - v námi rozebíraných souvislostech potom edukační změna. Jak jsme podrobněji vyložili na jiném místě (Janík, Maňák, Knecht, \& Němec, 2010, s. 10-11), pojem změna umožňuje zastřešit přeměny různého druhu, povahy, rozsahu, obsahu, dopadu apod. V závislosti na kontextu se někdy hovoří o změně, jindy o proměně. Zatímco změna je zpravidla vyvolána úsilím, jež je záměrné, plánované a řízené, proměna je spíše spojována s působením náhodných anebo záhad- 
ných sil. Reforma je typem edukační změny. Pojem reforma podle předních teoretiků $\mathrm{v}$ dané oblasti, odkazuje $\mathrm{k}$ systémové změně, která má určité charakteristiky (viz např. Gundem, Karseth, \& Sivesind, 2003). Jak uvádí citovaní autoři, změna je reformou když:

(1) je součástí širší reformy edukačního a sociálního systému; (2) je součástí komplexní reformy zacílené do všech úrovní vzdělávání; (3) klade si za cíl zavést soudržnost různých typů škol v rámci školského systému; (4) usiluje o soudržnost cílů, tj. staví na důležitých zastř̌ešujících cílech, které jsou „přeloženy“ do cílů všech školních předmětů a do kurikulárních programů na všech úrovních; (5) je zaváděna tak, že všechny důležité faktory a překážky (vč. vzdělávání učitelů a hodnocení) jsou zahrnuty do implementační strategie. (Gundem et al., 2003, s. 521)

S ohledem na toto vymezení se nelze ubránit otázce, zda to, co se aktuálně v našem školství odehrává, lze označovat jako reformu. Na základě výzkumného „pozorování“ reformy se domnívám, že změna, kterou aktuálně v České republice procházíme, $\mathrm{v}$ úplnosti nenabývá výše zmíněných charakteristik reformy. Přesto o ní zde hovořím jako o reformě, nebot' takto je v pedagogickém diskursu zavedena. $V$ zájmu hlubšího porozumění by však bylo potřebné analyzovat charakter současné vzdělávací změny v širším kontextu vzdělávací transformace a propracovat se tak $\mathrm{k}$ diferencovanějšímu náhledu. Četní autoři - mezi jinými i Průcha, Walterová a Mareš (2009) totiž poukazují na to, že

v současné době se v Evropě neprosazují jednorázové školské reformy, nýbrž probíhá dlouhodobý proces vzdělávací změny, doprovázený dílčími reformami a inovacemi, s cílem zlepšit kvalitu školního vzdělávání. Tento proces se označuje termínem „vzdělávací transformace“. (s. 305)

Další autoři upozorňují, že pro současný vývoj jsou spíše charakteristické

vzájemně se prolínající periody dekonstrukce, parciální stabilizace a systémové rekonstrukce, při níž již nejde pouze o postkomunistickou transformaci, ale o proces vyvolaný globalizací a společný s ostatními demokratickými změnami. (Kotásek, 2006, nestr.)

\subsection{Reforma čeho - reforma jaká}

Probíhající reforma je označována jako kurikulární. Kurikulární reforma je $\mathrm{z}$ logiky věci chápána jako jedna $\mathrm{z}$ dílčích reforem realizovaných $\mathrm{v}$ rámci 
školské reformy - obojí přitom lze považovat za součást vzdělávací transformace. Školskou reformu lze vymezit jako úředně organizovanou a zaváděnou změnu ve školské soustavě. Zatímco v případě školské reformy je předmětem reformování školská soustava, v případě kurikulární reformy je předmětem reformování kurikulum. Co si však představit pod tímto pojmem? V širším smyslu kurikulum zahrnuje „komplex problémů vztahujících se k řešení otázek proč, koho, v čem, jak, kdy, za jakých podmínek a s jakými očekávanými efekty vzdělávat" (Walterová, 1994, s. 13). V užším vymezení je kurikulum chápáno jako cílově obsahový program školního vzdělávání. Nabízí se otázka, jak je vlastně v současné diskusi chápáno kurikulum. Převážně jako kurikulární dokument, tj. jako text? Nebo jako souhrn interakcí rozvíjejících se kolem učiva mezi učitelem a žáky? Nebo jako obsah zkušeností, které žáci ve škole absolvují?

Je patrné, že příklon k určitému chápání pojmu kurikulum je ve svém důsledku zásadní pro porozumění tomu, o reformu čeho se jedná. Pokud bychom se přiklonili k širšímu vymezení, byli bychom nuceni chápat kurikulární reformu jako komplex systémových změn vztahujících se $\mathrm{k}$ těm nejdůležitějším otázkám, jež si lze v souvislosti se vzděláváním klást. Pokud bychom se přiklonili k užšímu vymezení, byli bychom nuceni chápat kurikulární reformu jako změnu v rovině cílů a obsahů školního vzdělávání. $\mathrm{Z}$ toho by vyplývalo, že např. změny $\mathrm{v}$ rovině metodické, tj. změny $\mathrm{v}$ rovině výukových postupů, by byly chápány nikoliv jako součást kurikulární reformy, nýbrž jako její (vedlejší) efekt.

Zde osobně vidím jeden z prakticky nejzávažnějších problémů současné kurikulární reformy $\mathrm{v}$ České republice. V mediální a laické zkratce vyjadřované hesly typu konec biflování či bude se učit jinak - byla reforma kurikula prezentována (také) jako prostředek změny výukových postupů či praktik, tj. potažmo kultury vyučování a učení. Problém je v tom, že kurikulární reforma nebyla (a asi ani v principu nemohla být) koncipována a dimenzována tak, aby toto mohla zajistit. Změna (zlepšení či rozvinutí) kultury vyučování a učení je dle mého názoru ambicí př́liš vysokou na to, aby ji bylo možné naplnit jen reformou kurikula. Jak vysvětlují různí autoři (srov. např. Stigler \& Hiebert, 1999, s. 97), vyučování a učení jsou kulturní praktiky, jež je z principu obtížné změnit, nebot' jsou založeny na nereflektovaných kulturních skriptech.

$\mathrm{Na}$ druhou stranu z uvedeného nelze vyvodit závěr o obecné neužitečnosti reformy kurikula ve vztahu k vyučování a učení. Určitou specifickou funkci ve 
vztahu k rozvíjení kultury vyučování a učení by reforma kurikula plnit měla. Měla by nastavit směřování a podmínky, jinak řečeno: měla by vytvořit rámec pro péči o kulturu ve školních třídách (podrobněji k tomu viz dále).

Pro hlubší orientaci v problematice reforem a reformování je důležité analyzovat, jakého charakteru je reforma, o níž se jedná. Odborná literatura $\mathrm{k}$ tomuto účelu nabízí rozlišení různých typů reforem (u nás $\mathrm{k}$ tomu viz např. Prokop, 2009); dále stručně prezentujeme některé $\mathrm{z}$ nich a připojujeme k nim komentář:

- Reforma nápravná (spasitelská) - dostává se na pořad dne, když např. srovnávací studie ukážou na špatné výsledky žáků. Ty potom reformu do jisté míry legitimizují - v mediální zkratce je reforma prezentována jakožto lék, tj. jako opatření, jehož cílem je zajistit dobré výsledky. Přitom ovšem nelze vyloučit, že takovou nápravnou reformu se „podaří" implementovat tak, že vedlejším efektem bude prohloubení problémů, které měla původně vyřešit. Může se tedy stát, že reforma se stane reformou cílem se míjející, či s nadsázkou řečeno reformou z řetězu utrženou.

- Reforma s reformou koexistující, popřr reforma reformě konkurující - typicky: pokud náprava, kterou měla sjednat jedna reforma, nenastává, objevuje se tendence doplňovat či nahrazovat ji reformou další - snad účinnější. Koexistence reforem je v lepším případě provázena tušením souvislostí, $\mathrm{v}$ horším případě jsou souvislosti netušené. Koexistence či konkurence více reforem je typická při „změně (politického) kursu“. Jde o situace, kdy nové je třeba zavést, avšak staré nelze jen tak odvrhnout, nebot’ se do něj již př́liš investovalo.

- Reforma naoko nevinná, v důsledku (pro někoho) likvidační - může to být třeba reforma založená např. na testování typu high stake, která je naoko legitimizována příslibem získání informací o výsledcích škol, avšak ve skutečnosti může jít o snahu redukovat sít škol apod.

- Reforma nezimplementovaná, neboli nereforma - jak známo, implementace, tj. zavedení do té míry důkladné, že se ideje obsažené v koncepcích objeví jako akceptované a každodenně praktikované v příslušné edukační realitě, je citlivým momentem každé reformy. Pokud se reformu nepodaří zimplementovat, nabývá charakteru nereformy, takže se od ní mnoho neočekává. Někdy může být nereforma lepším řešením než reforma, nebot' - jak se občas ozývá z praxe - dopřeje školám a učitelům klid na práci. 
Pokud bych měl přiřadit současnou českou kurikulární reformu k výše uvedeným charakteristikám, vyjádřil bych to asi takto. Domnívám se, že reforma byla zamýšlena a prezentována jako nápravná, oblast nápravy však nebyla jasně vymezena a pojmenována. Samotná otázka, co bylo (hlavním) důvodem a potažmo cílem české kurikulární reformy, zůstává i dnes otevřená. Byl tím důvodem pocit, že školy mají svázané ruce a že je třeba decentralizovat, a tudíž bylo cílem reformy toto nastolit? Nebo šlo o pocit, že kurikulární dokumenty jsou již zastaralé, že je třeba je inovovat? Nebo že výuka není dost kvalitní, a tudíž že je třeba ji zkvalitnit? Nebo že výsledky českých žáků jsou $\mathrm{v}$ určitých ohledech slabé a to je třeba změnit?

Nemohu se ubránit dojmu, že reforma se jednoznačně nepřihlásila k žádnému z uvedených důvodů a cílů a spíše všezahrnujícím způsobem slibovala všechno. Pokud bychom se zaměřili na naplnění zmiňovaných cílů, jeví se mi to tak, že došlo k určitému přepsání kurikulárních dokumentů - je však otázkou pro další analýzy, zda šlo o modernizaci. Jestli se reforma promítla do kultury škol, tak možná méně produktivním způsobem (školy hodnotí přepisování kurikula jako nepřiměřenou zátěž). Pokud jde o proměnu procesů vyučování a učení, to je otázka sama pro sebe - jak jsem uvedl výše, vyučování a učení jsou kulturně stabilizované praktiky, které se z podstaty věci obtížně mění (mnohé nasvědčuje tomu, že reforma do školních tříd prozatím výrazněji nepronikla, natož aby vyvolala změnu výukových praktik). A pokud jde o to, zda reforma způsobila lepší výsledky žákủ v testech PISA/TIMSS - při stávající (ne)koncepci monitoringu ve vzdělávání lze tuto otázku stěží zodpovědět.

Nejasnosti ohledně cílů a důvodů reformy mohou být dle mého názoru př́ičinou toho, že máme co do činění s reformou (prozatím) nezimplementovanou. Jak bylo zmíněno, implementace ve smyslu uskutečnění či naplnění určitých idejí je takový stav, kdy jsou tyto ideje akceptovány a běžně praktikovány. Dnes bychom si tudíž měli povšimnout, že výuka v duchu reformy je běžnou realitou našich škol. V souvislosti s tím se nabízí otázka, odkdy by bylo možné hovořit o tom, že došlo k implementaci kurikulární reformy? Bylo by to k 1. 9. 2005, kdy se státní koncepce RVP sesunula na úroveň škol? Nebo by to bylo k 1. 9. 2007, kdy se školní koncepce ŠVP sesunula na úroveň školních tř́́d? Nebo by to bylo až $\mathrm{v}$ okamžiku, kdy by se ideje $\mathrm{z}$ kurikula jakožto textu propracovaly do myslí učitelů? Nebo by to bylo až v př́ípadě, kdy by se reformní ideje běžně praktikovaly ve školních třídách? Naše výzkumy naznačují (Janík et al., 2011c, s. 401-410), že dvě posledně uváděné sku- 
tečnosti v očekávané míře nenastaly. Kromě toho se nemohu ubránit dojmu, že vedle kurikulární reformy (verze 2005) nastavující cíle a obsahy školního vzdělávání na vstupu se v posledních letech připojuje „reforma“, která má (spíše nepřiznanou) tendenci přenastavit řízení škol na základě orientace na výstupy - viz např. spory o pojetí reformy na pomezí bývalého Výzkumného ústavu pedagogického a někdejší České školní inspekce (Janík et al., 2011c, s. 387-388; Šíp, 2013, s. 247).

\subsection{K problému (na)časování aneb reforma uvnitř transformace?}

Z uvedeného mj. vyplývá, že problém kurikulární reformy a jejího vztahu $\mathrm{k}$ širšímu procesu vzdělávací transformace je třeba objasňovat také $\mathrm{s}$ přihlédnutím k jeho časové dynamice. Hlavní obtíží přitom zůstává určení počátku a případného konce reformy - přesněji řečeno vymezení fází transformačních a reformních procesů. $K$ řešení tohoto problému se pokusím přispět s využitím Fullanova modelu, resp. Birzeova čtyřfázového modelu post-socialistické transformace upraveného pro české prostředí Kotáskem (viz Greger, 2011, s. 16-17).

- Fullan (2007) rozlišuje tři fáze edukační změny: (1) iniciaci, (2) implementaci, (3) institucionalizaci.

- Birzea (2008) rozlišuje čtyři fáze post-socialistické transformace vzdělávání (pro Rumunsko): (1) de-strukturace, (2) stabilizace, (3) restrukturace, (4) proti-návrhy reforem.

- Kotásek (2006) rozlišuje pro ČR rovněž čtyři fáze, avšak s poněkud jinak rozloženými akcenty. Fáze 1 (dekonstrukce) je Kotáskem datována mezi roky 1990-1991; je podle něj typická vymezením se vůči stávajícímu stavu. Fázi 2 (parciální stabilizace) přiřazuje Kotásek letům 1991-2000 a vnímá ji jako období, pro něž je charakteristické přijímání ad hoc opatření a analýzy stavu a vývoje školství. Fáze 3 (systémová rekonstrukce) se podle Kotáska realizuje přibližně v letech 2001-2004; je zahájena přijetím Bílé knihy v roce 2001, který předestírá koncepci systémové reformy. Fázi 4 (implementace) Kotásek datuje k roku 2005, tj. poté, co byl přijat školský zákon č. 561/2004 Sb.

Kotásek i Birzea upozorňují, že tyto modely jsou určeny pro aplikaci na reformu (resp. transformaci) vzdělávacího systému jako celku. Kurikulární reforma je v tomto pohledu jen dílčí změnou jedné z částí systému. Budeme- 
li kurikulární reformu vnímat jako součást širší reformy (resp. vzdělávací transformace), můžeme konstatovat následující:

- Př́prava kurikulární reformy spadá do fáze systémové rekonstrukce, která je zahájena na přelomu milénia zveřejněním dvou zásadních dokumentů vzdělávací politiky - Koncepce vzdělávání... (MŠMT, 1999) a Bílá kniha (MŠMT, 2001). Za její završení lze považovat akt přijetí školského zákona č. 561/2004 Sb.

- Období, které následuje (2005+), lze označit za fázi plošné implementace, kdy se koncepce kurikulární reformy popsaná v RVP a souvisejících materiálech - od školského zákona až po manuály tvorby ŠVP - má propracovat do praxe.

- V posledních letech (2012+) se v souvislosti se zamýšlenou revizí rámcových vzdělávacích programů a dalšími aktivitami v oblasti vzdělávací a kurikulární politiky (např př́prava Strategie 2020) objevují náměty na více či méně výrazné přeorientování kurikulární reformy ${ }^{3}$.

Ve snaze o konkretizaci se nyní pokusím nahlédnout vývoj kurikulární reformy ještě jiným pohledem, a to s využitím tzv. ekvalizéru governance. ${ }^{4}$ Ekvalizér governance lze chápat jako analytický nástroj, který umožňuje graficky znázornit přibližné proporce vlivu jednotlivých aktérů ve školství, event. může jít o analýzu širších mechanismů fungování či řízení (ovládání) a správy školského systému.

3 Jak jsme upozornili na jiném místě (Janík et al., 2011c, s. 379), některé náměty J. Dobeše v roli ministra školství bylo možné interpretovat jako proti-návrhy vůči stávající reformě, jakkoliv týž současně tvrdil, že reforma je v pořádku. Aktuální postoj české vzdělávací politiky a řady expertů na vzdělávání - viz text Strategie 2020 - je vưči kurikulární reformě vstřícný - reforma nemá být zpochybňována, vedlo by to k demotivaci učitelů (srov. také Straková, 2013). Vedle toho se objevují i výrazněji kritická hodnocení současné české kurikulární reformy (viz např. Štech, 2013).

4 Governance jde za rámec tradičního řízení školství a zahrnuje celou řadu dalších aktivit souvisejících s „vládnutím (v) systému“ - zahrnuje např. „vyjasněnílkompetencí, odpovědností, formy výměny informací atd. a nastavení takových pravidel, která jsou nejpříznivější pro pedagogickou praxi“ (Veselý, 2013, s. 295), podrobněji k tomu viz také např. Kaščák a Pupala (2012, s. 20-22) a další. 


\section{Vývoj kurikulární reformy: analýza vlivu jednotlivých aktérů ve školství pomocí ekvalizéru governance}

S cílem vyložit problematiku řízení ve školství navrhl německý sociolog Uwe Schimank (2007) níže prezentovanou strukturu kategorií. V pozadí stojí předpoklad, že aktuální změny v řízení systému ve školství (včetně vysokého) lze vyjádřit tím, že se postihnou změny v koordinaci jednání mezi důležitými aktéry systému. Citovaný autor v této souvislosti vymezuje pět dimenzí a graficky je prezentuje jako ekvalizér governance (Obrázek 1).

S odkazem na Schimanka (2007) a Altrichtera (2009, s. 24-25) je lze pro účely tohoto textu v obecné rovině ${ }^{5}$ popsat takto:

1) Státní řízení na vstupu - řízení prostřednictvím regulace vstupu je ústř̌edním prvkem tradičního řízení školských systémů. Státní regulace na vstupu se většinou odehrává na základě kurikulárních dokumentů ve smyslu „plánů vzdělávání“.

2) Autoregulace učitelskou profesí - regulace na vstupu je tradičně spojena se značnou mírou autonomie učitelů při aplikaci tohoto „před-řízení“, zvláště pokud jde o otázky výuky. Tradičně je učitelskou profesí řízena zejména oblast výuky, a to v rámci tzv. metodické svobody; perspektivně se začíná učitelům svěřovat i řízení dalších oblastí - např. kurikula $s$ možnými přesahy až k ovlivňování celého školského systémů (srov. pojetí učitelství jako emancipované/angažované profese).

3) Řízení základních cílů zvnějšku - tento mechanismus spočívá v definování jasných cílů pro mezi-řízení autonomních škol (např. na základě vzdělávacích standardů), jejichž uplatnění a výsledky jsou ověřovány prostřednictvím různých postupů monitoringu a evaluace, přičemž informace z nich získané mohu být využívány jak pro řízení jednotlivé školy, tak pro řízení na úrovni celého systému.

4) Hierarchická autoregulace na úrovni jednotlivé školy - různé typy systémové koordinace se mohou odlišovat v tom, do jaké míry lze dílčí součásti systému (např. jednotlivé školy) chápat jako relativně akceschopné

\footnotetext{
Popis v obecné rovině je popisem využívajícím obecnou terminologii z oblasti vzdělávací politiky, teorie školy/kurikula/výuky a popř. dalších oborů. Jakých konkrétních podob obecně popisované „edukační reálie“ nabývají v konkrétních zemích či školsko-politických systémech a kontextech, to budiž předmětem zájmu samostatných studií, které tento text nemůže suplovat.
} 
organizační jednotky mající vnitřní hierarchii, vedení a odpovídající řídicí nástroje apod. Vedení vedením školy, posilování role vnitřního managementu školy - to jsou příklady reformních návrhů, které jsou na této úrovni analyzovány.

5) Konkurenční tlak a „ruka trhu“: školské systémy se liší v tom, jakou míru soutěže mezi jednotlivými školami připustí a využijí pro koordinaci systému. Dobře dostupné informace, zvýrazňování odlišností jednotlivých škol, malá míra omezování př́ístupu do škol a oceňování pro úspěšné - to jsou typické charakteristiky silně soutěžně orientovaných systémů.

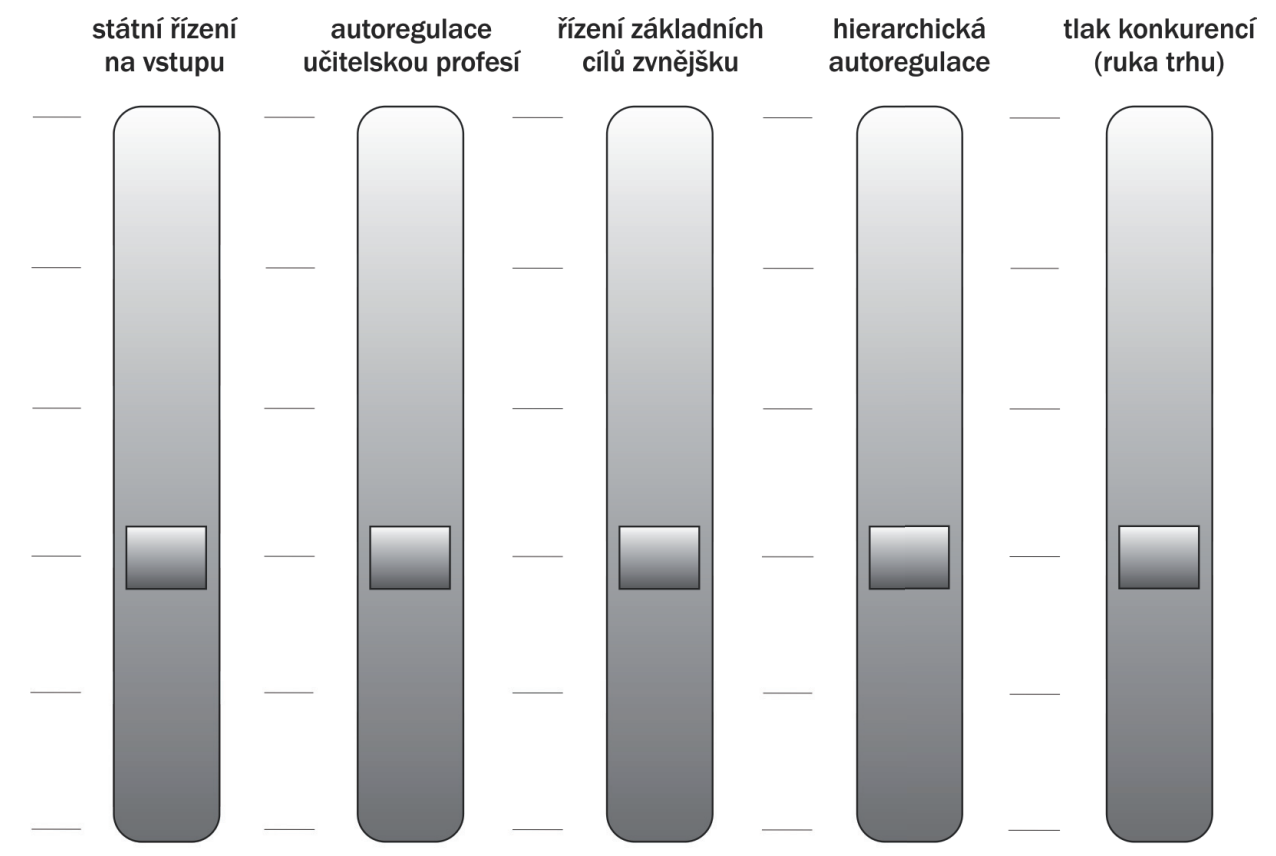

Obrázek 1. Ekvalizér governance

Nad rámec výkladu pěti dimenzí uváděných v ekvalizéru governance ještě stručně okomentujme jejich vybrané konstelace.

- Jakkoliv by se dimenze 1 a 3 samy o sobě mohly jevit jako protikladné, mnohdy v systému existují vedle sebe. Jde o to, že tradiční vzdělávací programy/plány jakožto nástroje státního ř́zení na vstupu jsou v systému doplňovány o vzdělávací standardy jakožto nástroje ř́zení odvozovaného $z$ výstupů. Děje se tak v systémech, kde se např. pod heslem rámcová 
kurikula vytvořil prostor pro kurikulární autonomii, avšak poté se stát ${ }^{6}$ z nějakého důvodu rozhodl „vzít si část své nabídky zpět“. Důvodem „částečného či úplného stornování kurikulární autonomie“ může být např. nezájem škol a učitelů či jejich nedostatečná kapacita/expertnost systémově se kurikulem zabývat.

- Vysoké hodnoty v dimenzích 2 a 4 by ukazovaly na silnou angažovanost učitelů, pedagogických sborů a vedení škol v otázkách školství. V odborné literatuře se $\mathrm{v}$ této souvislosti setkáváme $\mathrm{s}$ různými koncepcemi rozvíjení/zlepšování škol (angl. school development/improvement, něm. Schulentwicklung), v některých přístupech se lze setkat se zastřešujícím konceptem tvorba školy (něm. Gestaltung der Schule). Uvedené koncepty odkazují ke snaze rozvíjet (zkvalitňovat) školy a potažmo školské systémy prostřednictvím těch, kteří v nich profesionálně působí.

Představený model byl dle mých informací využit za účelem analýzy vývoje školství ve Spolkové republice Německo (Schimank, 2007) i v Rakousku (Altrichter, 2009). ${ }^{7}$ Pokusil jsem se jej uplatnit pro účely tohoto textu při analýze nedávného a předpokládaného budoucího vývoje v České republice. V dalším výkladu postupně nabízím čtyři varianty ekvalizéru governance. První (Obrázek 2) se vztahuje k situaci kurikulární reformy v době jejího uvedení na scénu (kolem roku 2005), druhá (Obrázek 3) znázorňuje situaci kurikulární reformy poté, co v průběhu své implementace doznala určitých deformací (kolem roku 2010). Komentáře ke druhé variantě ekvalizéru governance opírám o výzkumná zjištění shrnutá v předchozích publikacích našeho výzkumného týmu i dalších autorů (viz výše). Další dvě varianty ekvalizéru governance konstruuji na základě svého odhadu předpokládaného vývoje - jsou tedy nutně subjektivní. Jakkoliv se obávám vývoje nepříznivého (Obrázek 4), současně věřím ve vývoj - z mého pohledu - relativně přijatelný (Obrázek 5). Upozorňuji, že v celkovém pohledu se nejedná o rigorózní

6 Dodavatelem cílů zvnějšku nemusí být vždy stát - záleží totiž na tom, co přesně označuje slovo zvnějšku. Je otázkou pro samostatnou studii, jak vyhodnotit např. skutečnost, jsouli cíle do národního vzdělávacího systému dodávány z mezinárodně srovnávacích studií (např. PISA/TIMSS apod.). Nevymezí-li státní vzdělávací politika svůj vztah např. k těmto mezinárodně srovnávacím studiím, nelze jednoznačně rozhodnout, zda působí „zvnějšku“, nebo „zevnitř“.

7 Altrichter při popisu modernizace školství v Rakousku od devadesátých let 20. stol. do současnosti vymezuje následující tři fáze: (1) autonomizace škol; (2) posilování role školského managementu a nástrojů řízení uvnitř školy; (3) šok z mezinárodně srovnávací studie PISA a zavádění prvků řízení přesahující školy. 
analýzu, budiž proto vnímána ve smyslu předběžného sdělení, tedy spíše jen jako ilustrace naznačující určité trendy.

\subsection{Kurikulární reforma $v$ době uvedení na scénu}

Na Obrázku 2 je zhruba zachycen poměr vlivů sledovaných aktérů, jak byl převážně v deklaratorní rovině - nastavován kurikulární politikou kolem roku 2005, tj. v období plošného spouštění kurikulární reformy.

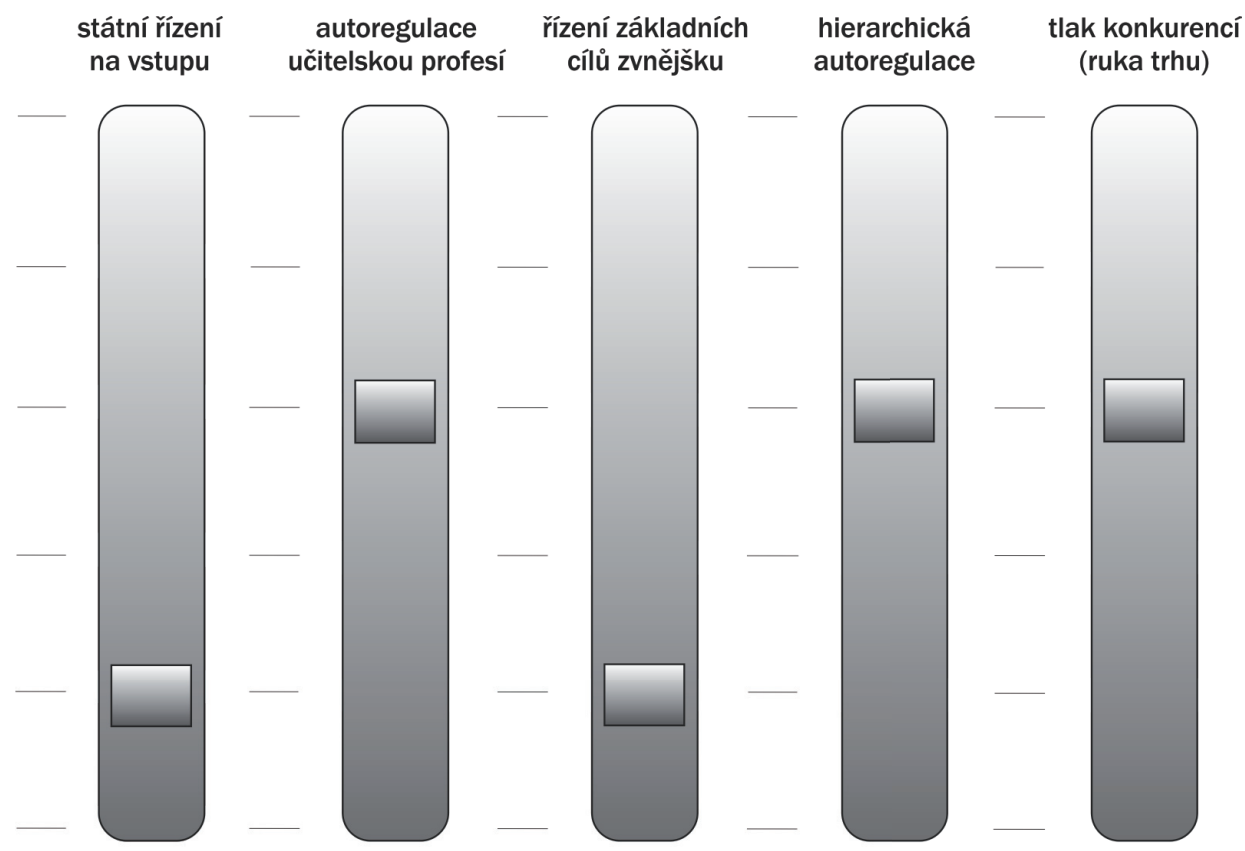

Obrázek 2. Proporce vlivu aktérů ve fázi uvedení kurikulární reformy na scénu

Kurikulární reforma (2005+) sice byla výrazem snahy o řízení cílů a obsahu státem na vstupu, avšak tím, že přišla s myšlenkou kurikula rámcového, resp. dvouúrovňového, a tedy s myšlenkou kurikulární decentralizace a částečné kurikulární autonomie, otevřela cestu k reálnému oslabení státního řízení školství na vstupu. S oslabením státního řízení na vstupu šla ruku v ruce také skutečnost, že základní cílovou kategorií vzdělávání se měly stát klíčové kompetence. Idea dvouúrovňového kurikula, vyjádřená sloganem „školy si mohou psát svá kurikula“, byla patrně spojena s předpokladem, že se v systému posílí autoregulace učitelskou profesí na straně jedné a hierarchická autoregulace na úrovni samotných škol na straně druhé. Tvorba ŠVP se měla 
stát prostředkem profilování a rozvoje školy. Naproti tomu řízení základních cílů zvnějšku (např. vlivem mezinárodně srovnávacích výzkumů nebo národního testování) nebylo kolem roku 2005 nijak výrazně přítomné, byt' skrytě do jisté míry působilo. Tlak ruky trhu se mírně zvýraznil - školní vzdělávací programy byly tu a tam pochopeny jako marketingový nástroj, různé soukromé firmy nabídly školám své produkty a služby i v oblasti tvorby kurikula (prozatím nikoliv v masovém měřítku).

\subsection{Kurikulární reforma ve fázi vytrácení}

Naše analýzy ukazují (Janík et al., 2011c, s. 394-395), že zavádění kurikulární reformy bylo procesem, v jehož průběhu došlo k určitému posunu akcentů, což se promítlo do změn v poměrech vlivu jednotlivých aktérů (viz Obrázek 3).

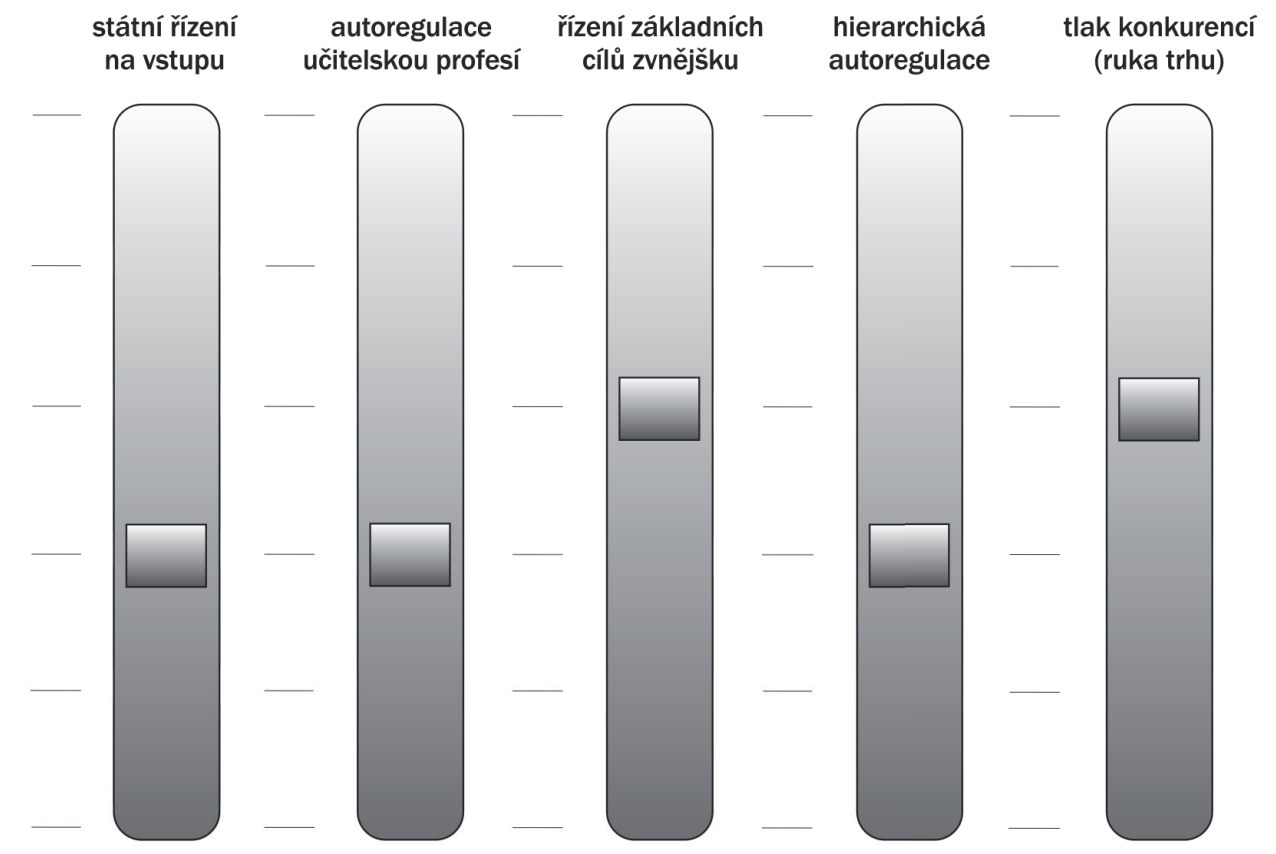

Obrázek 3. Proporce vlivu aktérů ve fázi vytrácení kurikulární reformy

Pokud bych měl označit časové období, v němž je posun akcentů nejlépe patrný, označil bych období působení Josefa Dobeše v roli ministra školství (červenec 2010 - březen 2012). Přestože oficiální ministerská rétorika držela kurikulární reformu ve hře, z realizovaných kroků lze usuzovat na její oslabování a postupné vytrácení (např. zrušení Výzkumného ústavu pedagogického, posilování vlivu České školní inspekce, avizovaná příprava 
evaluačních standardů a plošného testování). Současně se začalo ukazovat, že ideje dvojúrovňového kurikula - kurikulární decentralizace a částečné kurikulární autonomie v praxi již tolik netáhnou (srov. Prášilová, 2008, s. 274; Janík, Maňák, Knecht, \& Němec, 2010, s. 15-17, 21-23; Janík et al., 2011c, s. 399-407). Podobně idea klíčových kompetencí se prosazovala jen pozvolna a s užším záběrem (srov. Walterová et al., 2010, s. 152; Janík et al., 2011c, s. 384-387; Starý, Dvořák, Greger, \& Duschinská, 2012, s. 83-89; Štech, 2013). Problémem se naopak stal formalismus, do něhož mnohde tvorba školních vzdělávacích programů ve školách vyústila (srov. Janík et al., 2011c, s. 401-410; Starý, Dvořák, Greger, \& Duschinská, 2012, s. 83-89).

Namísto předpokládaného posílení autoregulace učitelskou profesí a hierarchické autoregulace na úrovni samotných škol docházelo vlivem formalismu spíše ke snižování kapacit obou těchto instancí - nejspíše proto, že jim nebyla poskytnuta koncepční systémová podpora (napřs kariérní systém pro učitele a ředitele, systém dalšího vzdělávání pedagogických pracovníků provázaný $s$ reformou).

Ve světle slabších výsledků českých žáků v mezinárodně srovnávacích studií PISA/TIMSS je avizováno posílení principu řízení základních cílů zvnějšku - začíná se pracovat na vytváření evaluačních standardů a potažmo na vývoji testování (plošného/celostátního - rétorika MŠMT za ministra Dobeše; výběrového - rétorika MŠMT za ministra Fialy) - podrobněji viz Veselý, Pavlovská a Voráč (2012). Tlak ruky trhu se postupně začíná zvýrazňovat - začíná být stále více patrné pronikání soukromých iniciativ do státního školství.

\subsection{Obávaný versus přijatelný scénář vývoje}

$\mathrm{V}$ návaznosti na uvedené se nelze ubránit otázce, jak se asi bude poměr vlivu jednotlivých aktérů vyvíjet v následujících letech. Na základě odhadu předpokládaného vývoje konstruuji další dvě varianty ekvalizéru governance. První varianta prezentuje vývoj, jehož se obávám (Obrázek 4). 


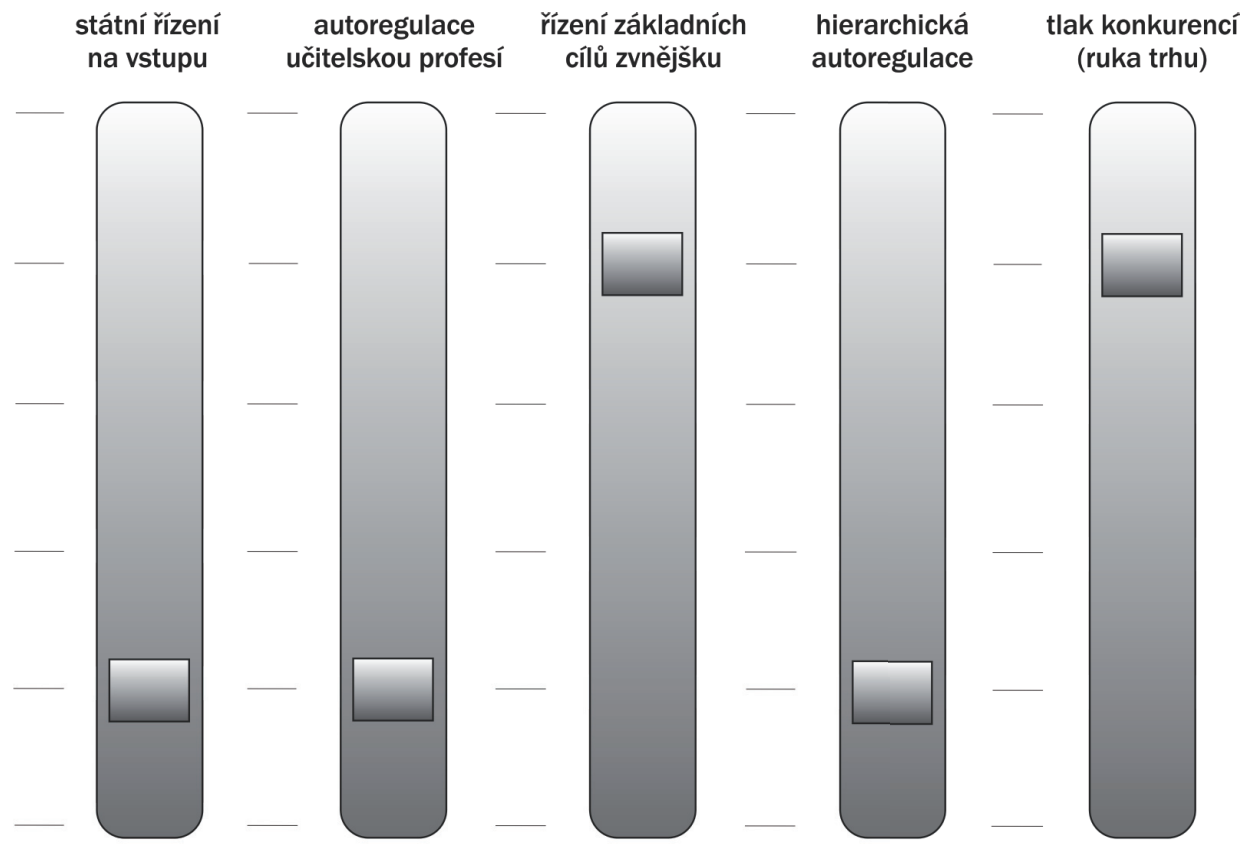

Obrázek 4. Proporce vlivu aktérů - obávaný scénář vývoje

Podle scénáře, který nazývám obávaný, dojde v následujících letech k dalšímu oslabení státního řízení na vstupu. Kurikulární politika nebude považována za prioritu - nastavování cílů a obsahů na vstupu bude odsunuto do pozadí. Oslabí také autoregulace učitelskou profesí a hierarchická autoregulace na úrovni samotných škol, a to nejspíše proto, že těmto dvěma oblastem nebude poskytnuta koncepční systémová podpora a současně budou učitelé a školy zatíženi tolika mimoběžnými úkoly, že se dostanou na hranici akceschopnosti. Řízení základních cílů zvnějšku výrazně posílí (nejspíše v důsledku šoku z PISA/TIMSS, pokud poukáží na další propad ve výsledcích českých žáků); zintenzivní se práce na evaluačních standardech a koncepcích testování. V důsledku toho ve školství obecně posílí princip soutěživosti - ruku v ruce s tím posílí ruka trhu (výrazněji se prosadí stínové vzdělávání).

Druhá varianta ekvalizéru governance znázorňuje vývoj, který bych považoval za relativně přijatelný (Obrázek 5). 


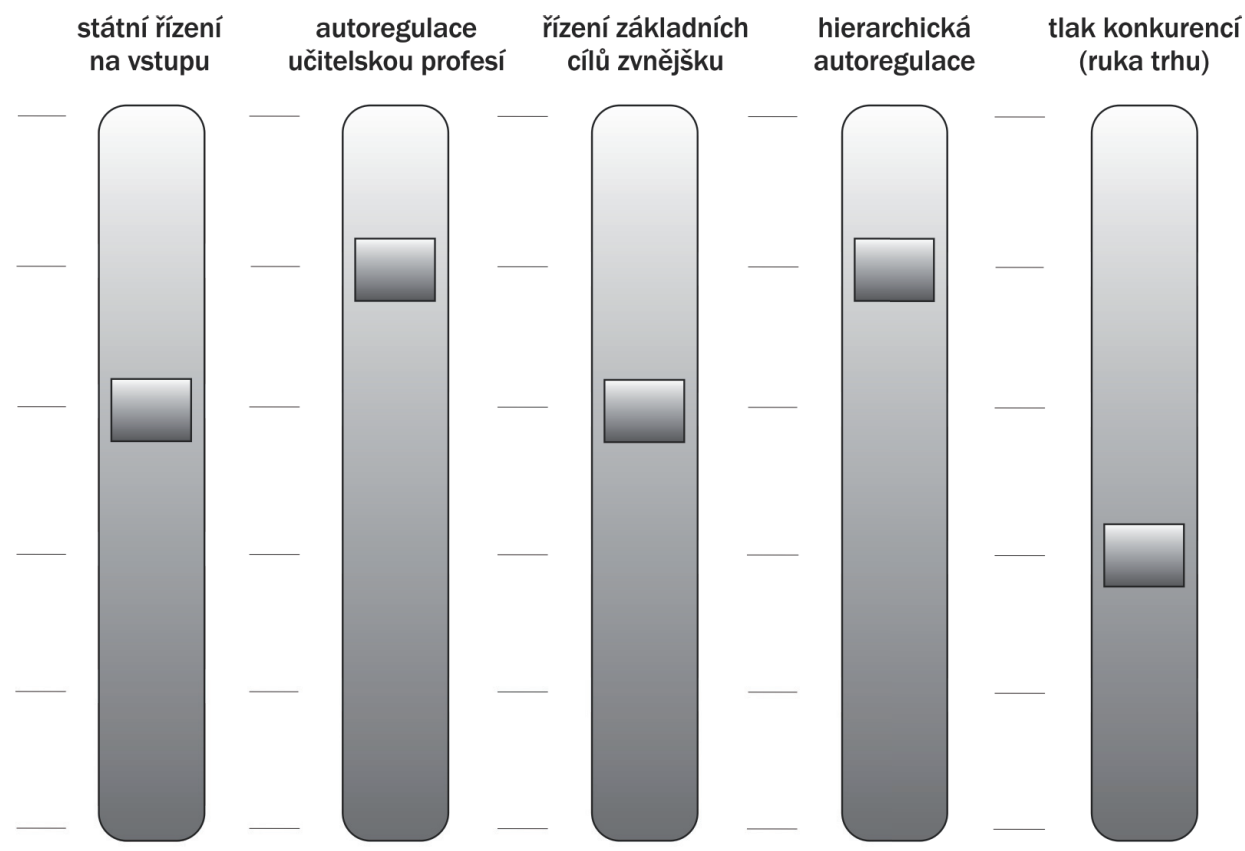

Obrázek 5. Proporce vlivu aktérů - přijatelný scénář vývoje

Osobně bych považoval za potřebné, aby v záležitostech školství posílila role státu (srov. Pelikán, 2012; Šíp, 2013; Veselý, 2013). ${ }^{8}$ Relativně silné státní ř́zení na vstupu by se mělo projevit zvýrazněním role státní kurikulární politiky. Právě do kurikulární politiky totiž spadá problematika konstituování školy ve smyslu vymezování její úlohy a funkce, jejích cílů a obsahů (tj. kurikula). Státní ř́zení cílů a obsahů na vstupu by mělo mít silné expertní zázemí (např. v podobě Národní rady vlády pro vzdělávání), z něhož by bylo možné reflektovat a vyhodnocovat iniciativy směřující k nastavování cílů zvnějšku (např. vliv mezinárodně srovnávacích studií PISA/TIMSS, vlivy testovacích agentur, vlivy zájmových skupin usilujících prosadit do kurikula určité ideologie či orientace, cíle a obsahy apod.).

Autoregulace učitelskou profesí a hierarchická autoregulace na úrovni samotných škol by měly výrazně posílit, nebot’ se jedná o kvalifikované instance, které jsou primárně ustaveny k tomu, aby školství konstituovaly. Vzhledem k tomu, že obě uvedené instance se pod vlivem „úřrednického“ ř́izení a souvisejícího formalismu dostaly na hranici svých kapacit a možností, bylo by

8 Viz k tomu také diskuse Mají výzkumníci odpovědnost za vzdělávací politiku? zachycená V. Ježkovou (2012) na 20. výroční konferenci České asociace pedagogického výzkumu (11. 9. 2012 na PedF UK v Praze). 
třeba posílit je dodáním přídavných kapacit (mentoři, konzultanti) ${ }^{9}$ a současně vyvázat je z mimoběžných úkolů (např. tvorba šablon), aby se ve školách zvýšil potenciál pro zvyšování kvality výuky. $\mathrm{V}$ důsledku relativně silného řízení státem, učitelskou profesí a samotnými školami by vliv ruky trhu byl méně výrazný. Regulaci ruky trhu považuji za nezbytnou, nebot' průlom tržních principů do školství by vedl k jeho privatizaci a k postupnému vytracení étosu podpory a pomoci prostřednictvím učitelského povolání a poslání.

Potud můj pokus o hrubou analýzu stávajícího stavu a předpokládaného vývoje ve školství pomocí ekvalizéru governance. Předložená skica budiž podkladem pro další výklad v této studii, v němž se adresněji zaměřuji na problém kurikulární reformy ve vztahu ke kultuře vyučování a učení.

\section{Od reformy kurikula k podpoře produktivní kultury vyučování a učení}

Dále $\mathrm{v}$ textu předkládám zamýšlení nad tím, $\mathrm{v}$ jaké vztahu může kurikulární reforma stát vůči snaze rozvíjet kulturu vyučování a učení ve školních třídách. Po rozboru problému relativně nízké účinnosti kurikulární reformy s ohledem na kvalitu výuky budu argumentovat pro potřebu rozvinutí kurikulární reformy do „programu“ podpory škol při rozvíjení produktivní kultury vyučování a učení ve školních třídách. V tomto programovém vyústění spočívá pointa předkládaného textu - osobně si na něm cením toho, že se vedle kritiky kurikulární reformy pokouší naznačit i horizont jejího dalšího možného směřování.

9 Je možné, že další etapa snah o rozvoj kvality ve školském systému nabyde podoby tzv. konzultantské reformy. Její podstata spočívá v tom, že se ve školách „objeví“ konzultanti, kteří nabídnou své služby. Nelze předem odhadnout, jaké efekty může tento typ reformy v konkrétním školském systému mít. Příznivé mohou být za předpokladu, že působení konzultantů bude kompetentní a na základě hluboké a rozumějící analýzy potřeb škol a učitelů bude směřovat do oblastí zakládajících podstatu školy (výchova a vzdělávání žáků - personalizace, socializace, enkulturace). Na rizika konzultantské reformy, v níž se angažují konzultanti, kteří naopak nedisponují příslušnými kompetencemi (včetně oborově didaktických), upozorňuje Altrichter (2009, s. 30), když uvádí: „Zkvalitnění výuky nezávisí jen na tom, zda umíme interpretovat zjištění z evaluací, ale také na tom, zda vidíme a dokážeme uplatnit alternativy vhodné z pohledu oborové didaktiky ... kromě toho jde také o to, zda jsme schopni učitele obsahově podporovat a motivovat při déletrvajících procesech utváření nové praxe výuky. $\mathrm{K}$ tomu nestačí jednorázově udělit radu na základě provedené evaluace; k tomu je zapotřebí širší spektrum kontinuálních konzultací, v nichž se propojí evaluační a oborově didaktická kvalifikace se schopností doprovázet vývojové procesy v reálných organizačních podmínkách daných škol.“ 


\subsection{Limitovaný vliv reformy na kvalitu výuky: důvod pro posun akcentů}

Provedené výzkumy naznačují, že kurikulární reforma tím, že je výrazně zatížena formalismem a do značné míry operuje „vně“ systému školních tříd, přináší pozitivní změny ve vyučování a učení pouze v omezené míře (Janík et al., 2011c, s. 407-410). Paradoxně se může reforma projevovat dokonce nepříznivě v tom, že bude učitele odvádět od toho, co je podstatného, tj. od přípravy a realizace kvalitní výuky ve školních třídách. Je zřejmé, že zde máme co do činění s obecným fenoménem intenzifikace práce učitele, jehož podstatu přiléhavě vystihuje Apple (1988, s. 41-45). ${ }^{10}$

Pokud jde o kurikulární reformu, osobně vidím problém v koncepci dvouúrovňového kurikula, a to zejména v myšlence „školy si píší své školní vzdělávací programy“. Plošné a povinné vytváření školních vzdělávacích programů nepovažuji v našich podmínkách za př́liš produktivní. ${ }^{11} \mathrm{Na}$ druhou stranu tím nechci popř́t význam kurikulárního dokumentu jako takového. Ten je i nadále důležitým nástrojem kulturní a vzdělávací politiky, nebot' jeho prostřednictvím jsou do školy zaváděny (a státem legitimizovány) určité cíle a určité obsahy vzdělávání - jde tedy o svého druhu kanonický text na straně jedné a o systém sloganů vzdělávací politiky na straně druhé. Kurikulum konstituuje školu tím, že vymezuje to, oč v ní má jít. Právě toto konstituování školy je hlavní funkcí kurikula. S rozpaky sleduji, jak se v posledních letech prosazuje představa, že kurikulární dokument by mohl být navíc nástrojem řízení školství (a škol) a též nástrojem jejich rozvoje (zkvalitňování) - to vše v jednom... Nevylučuji, že ve vyspělých školských systémech některých zemí

10 Citovaný autor vysvětluje, že termín intenzifikace odkazuje „k těm nejhmatatelnějším způsobům eroze privilegované činnosti pedagogických pracovníků ... nejlépe patrné jsou v chronickém pracovním přetížení, které je spojeno s časovou eskalací ... intenzifikace vede k nižší sociabilitě pracovníků - dochází k redukci volného času a autoregulace ... narůstá riziko izolace ... intenzifikace vede k zaměření pouze na to, co je kritické ... nejvýraznějším důsledkem intenzifikace může být snížení kvality při zachování kvantity ... regres se stává normou“ (Apple, 1988, s. 43-44). Adresně ve vztahu k učitelství autor jedním dechem dodává: „Procesy kontrolování, technizace a intenzifikace v učitelství spolu s proletarizací učitelské práce - to vše bylo původně nepřítomnou skutečností. A právě to bylo nesprávně identifikováno jako ukazatel nárůstu učitelského profesionalismu“ (Apple, 1988, s. 45).

11 Z našich výzkumů a obsahových analýz vzdělávacích programů je patrné, že školní vzdělávací programy do značné míry pojaly proreformní rétoriku, nebot’ ta byla „před-programována“ samotnou metodikou jejich tvorby. Otevřenou otázkou nicméně zůstává, do jaké míry bylo psaní kurikula ve školách psaním stimulujícím pedagogické uvažování? Do jaké míry bylo kolektivním psaním? Mimochodem, ukazuje se, že praxe má s psaním kurikula problém učitelé to v našem výzkumu (Janík et al., 2011c, s. 385) komentovali v duchu: proč popisovat to, co běžně děláme ... suplujeme práci někoho jiného - kurikulárních ústavů. 
se může dařit naplňovat i tyto funkce. Z výzkumů kurikulární reformy v České republice mám však dojem, že u nás se to nedaří (srov. Janík et al., 2011c, s. 401-404). Na druhou stranu je zřejmé, že pro některé školy představovala tvorba školních vzdělávacích programů hodnotnou př́ležitost k organizačnímu učení a potažmo k rozvoji školy (viz př́iklady uváděné in Pol et al., 2013, s. 48-55).

Přesto dle mého názoru řada problémů dvouúrovňového kurikula přetrvává. Domnívám se, že mnohé z nich jsou jednoduše způsobeny tím, že se od dvouúrovňového kurikula očekává př́liš mnoho. Mnohé z předpokládaných funkcí kurikula by lépe plnily jiné (metodické) postupy a nástroje - konkrétně např::

(1) Funkce spadající do oblasti řízení a rozvoje (zkvalitňování) školy by možná lépe plnily jiné nástroje - od práce s vizí (srov. Pol et al., 2005) až po propracované přístupy spadající do oblasti organizačního učení (srov. Pol et al., 2013).

(2) Funkce spadající do oblasti plánování (vč. koordinace) a zprostředkovávání cílů a obsahů vzdělávání by možná lépe plnily standardy (cílové, obsahové a standardy př́ležitostí k učení) a učebnice, přesněji řečeno koordinovaný systém standardů, učebnic a metodických př́ruček založený na solidních ontodidaktických a psychodidaktických analýzách.

(3) Funkce spadající do oblasti samotné realizace kurikula by bylo vhodnější řešit didaktickým konceptem a programem spočívajícím $v$ podpoře produktivní kultury vyučování a učení přímo ve školních třídách - v návaznosti na další vzdělávání kvalifikovaných a aprobovaných učitelů v rámci kariérního systému.

Finance a kapacity odborníků by se dle mého názoru měly investovat do toho, co je uváděno ve výše zmíněných bodech, spíše než do dvouúrovňového kurikula či do vývoje metodik (plošného/sumativního) testování. Vedle toho je samozřejmě zapotřebí dále pracovat na kvalitním (státním/národním) kurikulu (vč. jeho aktualizací) a uvádět toto kurikulum do systémových vazeb s tím, co je zmiňováno výše a též do vztahu s instancí kontroly (Česká školní inspekce). Jeden $z$ důvodů, proč se toto nedaří, spočívá v tom, že jednotliví aktéři (zejm. organizace MŠMT) mnohdy překračují své kompetence (ve smyslu pověření); vytvářejí mnohoúčelové konstrukty (např. dvouúrovňové kurikulum), přičemž (zdá se) není v silách nadřazené instance (MŠMT) 
zajistit podmínky pro jejich mnohoúčelové fungování. Na druhou stranu je to pochopitelné - snaha vytvářet mnohoúčelové konstrukty je obecným trendem - skoro každý mobil je dnes fotoaparát... funkční integrace je tudíž téma prioritního významu - má však své ale.

Reflexe a analýzy očekávaných funkcí a reálného fungování kurikula jsou informativní a měli bychom jim dát potřebný prostor. Shrnu-li své dosavadní úvahy, vidím pouze dvě podstatné funkce státního kurikula, a to: (1) vymezení cílů a obsahů školního vzdělávání a (2) jejich legitimizace (zdůvodnění). Pokud jde o tvorbu školního kurikula (ŠVP), ta jistě byla pro některé školy přínosem. Problém však vidím v tom, že byla (je) nadekretována plošně. Přikláněl bych se $\mathrm{k}$ tomu, aby školám, které by shledaly, že jim (tvorba) ŠVP nic nepřináší, nebo že mají jiné podstatnější problémy k řešení, bylo umožněno vyvázat se z této povinnosti.

Naše výzkumy naznačily, že na řadě škol je tvorba ŠVP vnímána jako něco, co odvádí učitele od samotné výuky, tedy od toho, co je jejich hlavním posláním a co zakládá důvod existence školy. Z uvedeného lze dovodit, že řešení vidím $\mathrm{k}$ obratu $\mathrm{k}$ samotné výuce, $\mathrm{tj}$. $\mathrm{k}$ obsahově založeným procesům vyučování a učení - při existenci kvalitního státního kurikulárního rámce, který by vymezil základní „pravidla hry“.

\subsection{Idea produktivní kultury vyučování a učení}

Jak uvádějí četní autoři (např. Stigler \& Hiebert, 1999, s. 137), realizovat změnu ve smyslu zvýšení kvality výuky znamená rozvíjet kulturu vyučování a učení př́mo ve školních třídách. Ideu rozvíjení produktivní kultury vyučování a učení proto prezentuji jako pověstný plán $b$ - pro př́pad, že by se ukázalo, že kurikulární reforma má pouze limitovaný dopad do praxe výuky.

Jak jsme podrobněji vyložili na jiném místě (Knecht et al., 2010, s. 38-39; Janík et al., 2013, s. 136-156), pojem kultura učení odkazuje k „časově ohraničenému souhrnu určitých forem učení a vyučovacích stylů a s nimi souvisejících antropologických, psychologických, společenských a pedagogických orientací" (Weinert, 1997, s. 12).

Jak upozorňují četní autoři (viz např. Reusser, 2001; Wiater, 2005), aktuálně „nová“ kultura vyučování a učení nachází teoretický fundament v teoriích pedagogického, psychologického a (oborově) didaktického konstruktivismu. 
Je pro ni charakteristické aktivní, konstruktivní, samostatné, motivované a celostní učení; učení bez tlaku na dosahované výsledky, které se odehrává ve společenství učících se jedinců, kteří jsou v přibývající míře nezávislí na vyučujícím - vzdělávají se pro situace každodenního života a jejich prostřednictvím. (Weinert, 1997, s. 12)

Důraz je kladen zejména na individualizaci učebních procesů, kognitivní aktivizaci žáků, zavádění autentických učebních úloh vyžadujících transfer naučeného do nových kontextů, generativní řešení problémů, verbalizaci procesu řešeníúloh, podporu metakognitivních procesů např. prostřednictvím rekapitulace učebního procesu apod. (srov. Weinert, 1997; Reusser, 2001; Wiater, 2005).

Reusser (2006, s. 161-164) na půdoryse klasického didaktického trojúhelníka rozebírá tři oblasti konstruktivistické kultury vyučování a učení (Obrázek 6). Ve vztahu k těmto třem oblastem autor formuluje klíčové otázky konstruktivistického pojetí: (a) učiva a učebních úloh, (b) učení a interakce procesů, (c) komunikační a učební podpory. Tyto tři oblasti podle autora představují nadoborovou strukturu, v níž se artikuluje pedagogické vidění, myšlení a jednání učitele.

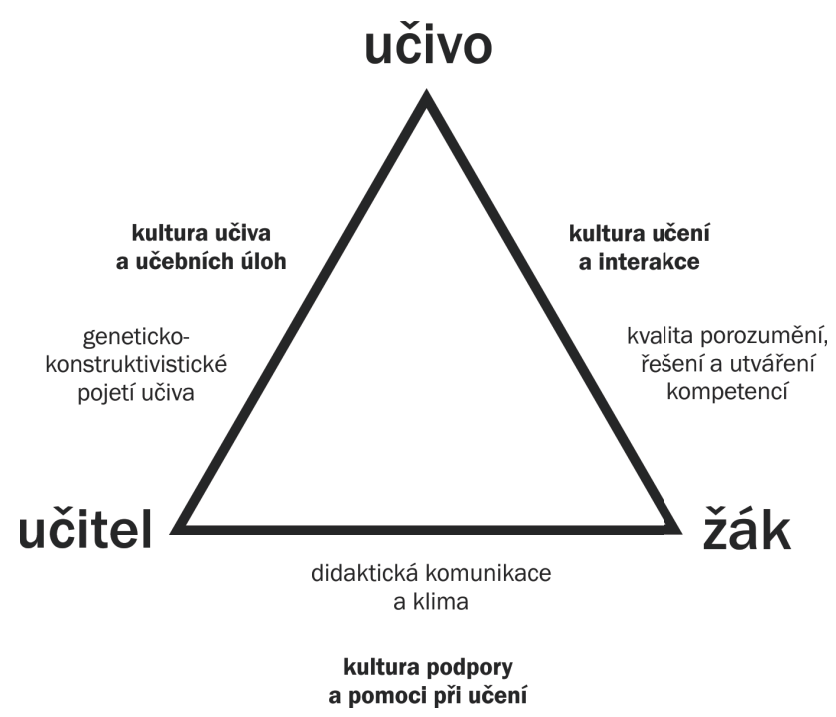

Obrázek 6. Artikulace konstruktivistické kultury vyučování a učení (upraveno podle Reussera, 2006, s. 162 - převod do českého jazyka proveden autorem tohoto textu) 
Jak podrobněji rozvádí Reusser (2006, s. 161-164), kulturu vyučování a učení lze v třech uvedených oblastech charakterizovat takto:

- Kultura učiva a učebních úloh - v konstruktivistickém pojímání učiva jde o to, že znalosti oborových obsahů nejsou prvořadě chápány jako „hotová matérie", nýbrž ve své konstrukci jako něco, co se utváří. Reusser zde odkazuje ke strukturně genetickému př́ístupu Piageta. Odtud vyplývá zájem konstruktivisticky orientovaných didaktiků a učitelů o kontext objevování, z něhož teprve vyrůstají smysluplné cíle a standardy učení, nejde tedy pouze o pojetí obsahu jakožto konečného produktu. Jak autor uvádí, „kultivovat strukturně genetický přístup k vědění potom znamená hledat didaktické možnosti jeho převedení do tekuté podoby (Verflüssigung), aby se tak vytvořila příležitost pro samostatné a v ideálním prŕípadě problémově orientované re-konstruování obsahu (stoffbezogene Interaktivität) při učení" (Reusser, 2006, s. 161-162). Tento př́ístup je charakteristický svým dynamickým pojímáním struktur učiva. Klíčovými otázkami konstruktivistického pojetí učiva jsou např:: Lze s obsahem (předmětem učení) interagovat variabilně a v různých kontextech? Jsou procesy zkoumání, utváření a aplikování obsahu podporovány prostřednictvím kognitivně a motivačně aktivizujících úloh vztažených $\mathrm{k}$ tomu, co je jádrové? Je reflektována multiperspektivita vědění? Je k dispozici prostor pro vyjednávání pozic a perspektiv, nebo je žákům předkládáno hotové učebnicové vědění? (volně podle Reussera, 2006, s. 162).

- Kultura učení a interakce - jak uvádí citovaný autor (Reusser, 2006, s. 163), konstruktivisticky pojímané učení a interakce se projevuje dostatkem příležitostí ke „zkušenostně orientovanému, smysluplnému, problémově orientovanému a dialogickému učení, $\mathrm{k}$ učení, $\mathrm{v}$ němž se při konfrontaci věcného a sociálního světa a při používání kulturních nástrojů a symbolických systémů utváří nové vědění, integruje se do vědění stávajícího a propojuje se s ním. Jak vlastní učení objevováním a učení kooperativní, tak receptivní učení a učení následováním (nachvollziehendes Lernen) představují ryzí konstrukční výkon - probíhají-li s orientací na porozumění“. Dalšími charakteristikami konstruktivistického pojetí učení a interakce jsou podle autora: situovanost a sociální zakotvenost, jakož i další kvality, v nichž dochází $\mathrm{k}$ iniciaci a podpoře metakognitivní regulace a k reflexi pracovních a učebních procesů. Klíčovými otázkami konstruktivistického pojetí učení a interakce jsou napřs: Existuje rovnováha mezi učením problémově orientovaným a smysluplným, učením individuálním a koopera- 
tivním, učením autoregulovaným a receptivním? Pracuje se s představami a zkušenostmi žáků? Mají žáci př́ležitost realizovat aktivity utvářející zkušenosti a znalosti tak, aby mohli sami definovat př́slušné učební situace? Je podporováno střídání sociální interakce a kooperace s vlastními aktivitami a badatelstvím? Diskutuje se, vyjednává se, spolupracuje se? Je podněcována (sebe)reflexe učení, jsou podporovány procesní učební cíle jako např. osvojování strategií učení? Umožňuje učební prostředí realizovat přirozenou diferenciaci a přispívá současně k heterogenitě učební skupiny? (volně podle Reussera, 2006, s. 163).

- Kultura didaktické komunikační a učební podpory - v konstruktivisticky chápané výuce dochází podle citovaného autora k omezení prrímého řízení učitelem, hledají se cesty adaptivní podpory žáků, akceptuje se a podporuje se jejich autonomie jako cíl a současně jako procesuální předpoklad výuky. Klíčovými otázkami konstruktivistického pojetí didaktické komunikační a učební podpory jsou napřs: Objevují se př́ležitosti k socio-kognitivnímu učení na principu učňovství, kdy učitel působí jako expert oboru a reprezentant kulturně akceptovaného vědění a současně jako konkrétní model chování (tutor, opora v učení, kouč, facilitátor)? Jsou žáci adaptivně podporováni jak na rovině oborové, tak na rovině učebních a interakčních procesů, dostává se jim od učitele a od spolužáků podpory a rady při jejich učení? Iniciuje učitel náročné pojmotvorné procesy a nabízí přitom žákům podporu s ohledem na obsah a proces učení? Podporuje učitel dialog s žáky a mezi žáky a podporuje kladení otázek, vyjednávání významů, kritizování hypotéz, diskusi rozporů a chyb? Slouží hodnocení a reflexe pracovních a učebních procesů jako reciproční zpětná vazba a jsou k dispozici kritéria úspěšnosti? (volně podle Reussera, 2006, s. 164).

V našem přístupu dodáváme $\mathrm{k}$ termínu kultura vyučování a učení přívlastek produktivní, který má být vnímán jako určitá protiváha vůči přívlastku receptivní, který dle některých výzkumů vystihuje charakter stávající výukové praxe (za výuku angličtiny srov. např. Šebestová, Najvar, \& Janík, 2011, s. 339-341, za výuku dějepisu srov. např. Gracová \& Labischová, 2012, s. 529-531 a další). Produktivní kultura vyučování a učení je dána zejména: náročnými a motivujícími učebními úlohami, kognitivní aktivizací žáků, konstruktivní prací s chybami, kumulativností učebních procesů, transferem naučeného, rozvíjením žákovské metakognice apod. Uváděné obecnější pedagogické a psychologické charakteristiky produktivní kultury vyučová- 
ní a učení do značné míry korespondují se specifičtějšími charakteristikami rozpracovávanými v oborových didaktikách (např. za didaktiku matematiky viz Stehlíková, 2007) a jsou prakticky rozvíjeny v řadě intervenčních programů směřujících ke zvyšování kvality či (procesuální) efektivnosti výuky např. německý program SINUS. ${ }^{12}$

Kulturu vyučování a učení nelze rozvíjet jinak než v kontextu kultury školy. V tomto ohledu je u nás na co navazovat. Práce Pola et al. (2005), Světlíka (2006), Hlouškové (2008) a dalších autorů představují teoreticko-metodologickou i empiricko-výzkumnou oporu pro toto úsilí. Lze předpokládat, že by se začalo pracovat v modu „,̌̌kola má kulturu“, přičemž její rozvoj by spočíval v práci na stávající kultuře, která by se rozvíjela směrem ke strategicky žádoucí - produktivní - variantě (podrobněji k této problematice viz Hloušková, 2008, s. 53-69).

\section{Závěrem: podpora produktivní kultury vyučování a učení}

V tomto textu jsem se pokusil vymezit a analyzovat „problém“ kurikulární reformy a jejího vztahu ke kultuře vyučování a učení. Současnou kurikulární reformu jsem komentoval $\mathrm{v}$ kontextu vzdělávací transformace a zamýšlel jsem se nad jejím předmětem, charakterem a způsobem realizace. Pomocí tzv. ekvalizéru governance jsem rozebíral problém načasování reformy, a to v kontextu analýzy širších mechanismů fungování a ovládání školského systému. V závěru jsem prezentoval své přesvědčení, že současná kurikulární reforma stěží pozvedne kvalitu výuky, nebot' její implementace vyústila v nezvladatelný formalismus. Pokusil jsem se argumentovat, že cesta ke kvalitě výuky spočívá $\mathrm{v}$ podpoře produktivní kultury vyučování a učení přímo ve školních třridách.

Nezastírám, že cesty $\mathrm{k}$ produktivní kultuře vyučování a učení jsou z nejnáročnějších, po kterých se lze vydat, avšak současně jsou to cesty, které slibují někam vést. S ohledem na stabilitu vyučování a učení nicméně nelze očekávat rychlé úspěchy. Podporu produktivní kultury vyučování a učení ve školních třídách je proto třeba koncipovat jako dlouhodobý „program“ vedený několika tezemi (srov. Slavík \& Janík, 2012; Janík et al., 2013).

12 Program SINUS: Zvyšování efektivnosti výuky matematiky a př́rodních věd byl založen na sítování škol, jimž byla poskytována podpora (z) institucí zabývajících se didaktikou matematiky a př́rodních věd a výzkumem vzdělávání (http://www.sinus-transfer.de). 
- Při celkovém posílení významu kurikulární politiky je třeba koncipovat státní kurikulum tak, aby představovalo rámec vymezující prostor pro realizaci snah směřujících $\mathrm{k}$ podpoře produktivní kultury učení; prostřednictvím relativně výstižných formulací vymezit hodnotné cíle obecné i specifické pro jednotlivé vzdělávací oblasti a obory. Na úrovni základní školy se zaměřit nejspíše na zajištování a upevňování základních znalostí a dovedností - lze se přitom opríit o koncept gramotností ve smyslu německého termínu Grundbildung, tj. vzdělanostního základu odkazujícího ke schopnosti vůbec se podílet na určitých oblastech (oborech) lidských aktivit.

- V oblasti tvorby, výzkumu a teorie důsledněji realizovat obrat k edukační realitě, k procesům obsahově založeného vyučování a učení; propracovat obsah produktivní kultury vyučování a učení a v souvislosti s tím rozvinout kurikulární reformu do polohy (oborově) didaktické a nasměrovat profesionální podporu přímo do školních tříd.

- V komunitách praxe podporovaných teoretiky a výzkumníky z fakult se zaměřit na kvalitu transformace obsahu v procesech vyučování a učení; při reflexi v těchto komunitách praxe rozvíjet schopnost argumentovat výběr relativně nejlepší či v určitém ohledu zlepšující varianty didaktického postupu (alterace).

- Rozvinout doprovodný výzkum zaměřený na kurikulární a didaktické praktiky (na konkrétní akty práce s učivem ve školních třídách, na konkrétní vzorce interakcí mezi učitelem, žáky a učivem apod.), který by uvedeným snahám poskytoval směr a orientaci.

$\mathrm{Z}$ pohledu teorie by zastřešující cíl tohoto úsilí měl spočívat v rozvíjení didaktického metajazyka, který by mu dodal jemně diferencující terminologii, čímž by umožnil do hloubky porozumět procesům vyučování a učení a podpořil by profesionalizaci v této oblasti. Že se jedná o velmi ambiciózní a náročný program rozvoje kvality školního vzdělávání, je z uvedeného patrné. Právě proto je výzvou hodnou následování.

\section{Literatura}

Altrichter, H. (2009). Lehrerfortbildung im Kontext von Veränderungen im Schulwesen. In F. H. Müller, A. Eichenberger, M. Lüders, \& J. Mayr (Eds.), Lehrerinnen und Lehrer lernen: Konzepte und Befunde zur Lehrerfortbildung (s. 17-34). Münster: Waxmann.

Apple, M. W. (1988). Teachers and texts: A political economy of class and gender relations in Education. New York and London: Routledge. 
Birzea, C. (2008). Back to Europe and the second transition in Central Eastern Europe. Orbis scholae, 2(2), 105-113.

Dvořák, D. (2012). Od osnov ke standardům. Proměny kurikulární teorie a praxe. Praha: Univerzita Karlova v Praze - Pedagogická fakulta.

Fullan, M. (2007). The new meaning of educational change. New York: Teachers College Press.

Gracová, B., \& Labischová, D. (2012). Současná teorie a praxe dějepisného vzdělávání na školách. Pedagogická orientace, 22(4), 516-543.

Greger, D. (2011). Dvacet let českého školství optikou teorií změny vzdělávání v post socialistických zemích. Orbis scholae, 5(1), 9-22.

Gundem, B. B., Karseth, B., \& Sivesind, K. (2003). Curriculum theory and research in Norway: Traditions, trends and challenges. In W. F. Pinar (Ed.), International handbook of curriculum research (s. 517-534). London: Lawrence Erlbaum Associates.

Hloušková, L. (2008). Proměna kultury školy v pedagogických diskurzech. Brno: FF MU.

Hrubý, D. (2011). Kurikulární reforma přišla pozdě. Pedagogická orientace, 21(4), 474-480.

Janík, T., Janko, T., Knecht, P., Kubiatko, M., Najvar, P., Pavlas, T., Slavík, J., Solnička, D., \& Vlčková, K. (2010b). Kurikulární reforma na gymnáziích: výsledky dotazníkového šetření. Praha: VÚP.

Janík, T., Knecht, P., Kubiatko, M., Pavlas, T., Slavík, J., Solnička, D., \& Vlček, P. (2011b). Kvalita školy a kurikula: od expertního šetření ke standardu kvality. Praha: VÚP.

Janík, T., Knecht, P., Najvar, P., Píšová, M., \& Slavík, J. (2011c). Kurikulární reforma na gymnáziích: výzkumná zjištění a doporučení. Pedagogická orientace, 21(4), 375-415.

Janík, T., Knecht, P., Najvar, P., Pavlas, T., Slavík, J., \& Solnička, D. (2010a). Kurikulární reforma na gymnáziích $v$ rozhovorech s koordinátory pilotních a partnerských škol. Praha: VÚP.

Janík, T., Maňák, J., Knecht, P., \& Němec, J. (2010). Proměny kurikula současné české školy: vize a realita. Orbis scholae, 3(3), 9-35.

Janík, T., Najvar, P., \& Solnička, D. (2011). Od idejí k implementaci: kurikulární reforma v rozhovorech s řediteli (nepilotních) gymnázií. Orbis scholae, 5(3), 63-85.

Janík, T., Slavík, J., Najvar, P., Hajdušová, L., Hesová, A., Lukavský, J., Minaříková, E., Píšová, M., \& Švecová, Z. (2011a). Kurikulární reforma na gymnáziích: od virtuálních hospitací $k$ videostudiím. Praha: VÚP.

Janík, T., Slavík, J., Mužík, V., Trna, J., Janko, T., Lokajíčková, V., Lukavský, J., Minaříková, E., Sliacký, J., Šalamounová, Z., Šebestová, S., Vondrová, N., Zlatníček, P. (2013). Kvalita (ve) vzdělávání: obsahově zaměřený př́stup ke zkoumání a zlepšování výuky. Brno: Masarykova univerzita.

Ježková, V. (2012). XX. výroční konference České asociace pedagogického výzkumu. Orbis scholae, 6(3), 138-146.

Kaščák, O., \& Pupala, B. (2012). Škola zlatých golierov: Vzdelávanie v ére neoliberalismu. Praha: SLON.

Knecht, P., Janík, T., Najvar, P., Najvarová, V., \& Vlčková, K. (2010). Příležitosti k rozvíjení kompetence k řešení problému ve výuce na základních školách. Orbis scholae, 4(3), 37-62.

Kotásek, J. (2006). Bílá kniha po pěti letech. Učitelské listy, 23. 2. 2006. Dostupné z http://www. ucitelske-listy.cz/2009/11/jiri-kotasek-bila-kniha-po-peti-letech.html

Kratochvílová, J. (2007). Učitelé škol v nové roli „tvůrců“ školního kurikula. Orbis scholae, 2(1), 101-110.

Kuhn, J. (2011). Kurikulární reforma v poločase. Pedagogická orientace, 21(4), 480-486.

Maňák, J. (2003). Problém - kurikulum. Pedagogická orientace, 13(3), 62-69. 
MŠMT (1999). Koncepce vzdělávání a rozvoje vzdělávací soustavy v České republice. Praha: MŠMT.

MŠMT (2001). Národní program rozvoje vzdělávání v České republice (Bíla kniha). Praha: MŠMT.

Pelikán, J. (2012). Státní vzdělávací politika jako významný problém českého školství. Pedagogická orientace, 22(4), 581-595.

Píšová, M., Kostková, K., Janík, T., Doulík, P., Hajdušková, L., Knecht, P., Lukavský, J., Najvar, P., Najvarová, V., Maňák, J., Pavlas, T., Slavík, J., Spurná, M., Stehlíková, N., Škoda, J., \& Vlček, P. (2011). Kurikulární reforma na gymnáziích. Případové studie tvorby kurikula. Praha: VÚP.

Pol, M., Hloušková, L., Lazarová, B., Novotný, P., Sedláček, M. (2013). Když se školy učí. Brno: Masarykova univerzita.

Pol, M., Hloušková, L., Novotný, P., \& Zounek, J. (Eds.). (2005). Kultura školy: příspěvek k výzkumu a rozvoji. Brno: Masarykova univerzita.

Prášilová, M. (2008). ŠVP - rozhodování a odpovědnost. In P. Franiok \& D. Knotová (Eds.), Učitel a žák v současné škole (s. 273-279). Brno: Masarykova univerzita.

Prokop, J. (2009). Reformy školství a vzdělávání ve světě. In J. Průcha (Ed.), Pedagogická encyklopedie (s. 564-569). Praha: Portál.

Průcha, J., Walterová, E., \& Mareš, J. (2009). Pedagogický slovník. Praha: Portál.

Reusser, K. (2001). Unterricht zwischen Wissensvermittlung und Lernen lernen. In C. Finkbeiner \& G. W. Schnittmann (Eds.), Lehren und Lernen im Kontext empirischer Forschung und Fachdidaktik (s. 106-140). Donauwörth: Auer Verlag.

Reusser, K. (2006). Konstruktivismus - vom epistemologischen Leitbegriff zur Erneuerung der didaktischen Kultur. In M. Baer, M. Fuchs, P. Füglister, K. Reusser, \& H. Wyss (Eds.), Didaktik auf psychologisher Grundlage. Von Hans Aeblis kognitionspsychologischer Didaktik zur modernen Lehr- und Lernforschung (s. 151-168). Bern: H.E.P. Verlag AG.

Schimank, U. (2007). Die Governance-Perspektive: Analytisches Potential und anstehende konzeptionelle Fragen. In H. Altrichter, T. Brüsemeister, \& J. Wissinger (Eds.), Educational Governance - Handlungskoordination und Steuerung im Bildungssystem (s. 9-43). Wiesbaden: Verlag für Sozialwissenschaften.

Skalková, J. (2005). Rámcové vzdělávací programy - dlouhodobý úkol. Pedagogika, 55(1), 4-19.

Skalková, J. (2007). Kategorie cíle, kompetence, jejich vzájemný vztah a význam pro obsah vzdělávání v kontextu současnosti. Orbis scholae, 2(1), 7-20.

Slavík, J., \& Janík, T. (2012). Kvalita výuky: obsahově zaměřený př́ístup ke studiu procesů vyučování a učení. Pedagogika, 62(3), 262-287.

Spilková, V. (2005). Rámcový vzdělávací program pro základní vzdělávání v kontextu transformace českého školství. Pedagogika, 55(1), 20-25.

Starý, K., Dvořák, D., Greger, D., \& Duschinská, K. (2012). Profesní rozvoj učitelů: Podpora učitelů pro zlepšování výsledků žáků. Praha: Karolinum.

Stehlíková, N. (2007). Charakteristika kultury vyučování v matematice. In A. Hošpesová, N. Stehlíková, \& M. Tichá (Eds.), Cesty zdokonalování kultury vyučování matematice (s. 1348). České Budějovice: JČU v Českých Budějovicích.

Stigler, J. W., \& Hiebert, J. (1999). The teaching gap. New York: Free Press.

Straková, J. (2007). Kurikulární reforma z pohledu šetření Kalibro. Pedagogika, 57(1), 21-36.

Straková, J. (2010). Postoje českých učitelů k hlavním prioritám vzdělávací politiky. In R. Váňová \& H. Krykorková (Eds.), Učitel v současné škole (s. 167-175). Praha: FF UK.

Straková, J. (2013). Jak dál s kutikulární reformou. Pedagogická orientace, 23(5), 735-744. 
Světlík, J. (2006). Marketingové ř́zení školy. Praha: ASPI.

Šebestová, S., Najvar, P., \& Janík, T. (2011). Příležitosti k rozvíjení řečových dovedností ve výuce anglického jazyka: samostatně anebo v integraci. Pedagogická orientace, 21(3), 322-357.

Šíp, R. (2013). Zdroj politické neúčinnosti pedagogické komunity: Nesounáležitost praktiků a teoretiků. Pedagogická orientace, 23(2), 245-256.

Štech, S. (2003). Vzdělávací programy mají umožnit poznání aneb Brána mysli otevřená. In A. Brabcová (Ed.), Brána muzea otevřená. Průvodce na cestě muzea k lidem a lidí do muzea (s. 66-85). Praha: Open Society Fund.

Štech, S. (2006). Reforma kurikula jako kulturní změna. In V. Zikmundová (Ed.), Rámcový vzdělávací program a výtvarná výchova. Sympozium ČS INSEA Plzeň, 16.-18. ř́jna 2004 (s. 11-19). Plzeň: Západočeská univerzita Plzeň.

Štech, S. (2009). Zřetel k učivu a problém dvou modelů kurikula. Pedagogika, 59(2), 105-116.

Štech, S. (2013). Když je kurikulární reforma evidence-less. Pedagogická orientace, 23(5), 615-663.

Tupý, J. (2011). Výsledky výzkumu Kvalitní škola z pohledu tvůrce rámcových vzdělávacích programů. Pedagogická orientace, 21(4), 486-492.

Tupý, J. (2014). Tvorba kurikulárních dokumentů v ČR. Historicko-analytický pohled na prípravu kurikulárních dokumentů pro základní vzdělávání v letech 1989 až 2013. Brno: Masarykova univerzita ( $\mathrm{v}$ tisku).

Urbánek, P., \& Wernerová, J. (2008). Studenti učitelství a jejich vnímání realizace kurikulární reformy. In P. Franiok \& D. Knotová (Eds.), Učitel a žák v současné škole (s. 218-225). Brno: Masarykova univerzita.

Veselý, A. (2011). Veřejněpolitický a „klasický“ sociálněvědní výzkum: podobnosti a odlišnosti. In M. Nekola, H. Geissler, \& M. Mouralová (Eds.), Současné metodologické otázky veřejné politiky (s. 12-63). Praha: Karolinum.

Veselý, A. (2013). Vzdělávací politika: rozdílná vymezení, před poklady a implikace. Pedagogická orientace, 23(3), 279-297.

Veselý, A., Pavlovská, V., \& Voráč, M. (2012). Celostátní testování žáků v českých denících v letech 1990-2011. Orbis scholae, 6(3), 99-118.

Walterová, E. (1994). Kurikulum. Proměny a trendy v mezinárodní perspektivě. Brno: Masarykova univerzita.

Walterová, E., Černý, K., Greger, D., \& Chvál, M. (2010). Školství - věc (ne)veřejná. Praha: Karolinum.

Weinert, F. E. (1997). Lernkultur im Wandel. In E. Beck, T. Guldimann, \& M. Zutavern (Eds.), Lernkultur im Wandel. Tagungsband der Schweizerischen Gesellschaft für Lehrerinen- und Lehrerbildung und der Schweizerischen Gesellschaft für Bildungsforschung (s. 11-29). St. Gallen: UVK.

Wiater, W. (2005). Die neue Lernkultur im Widerstreit der Meinungen. In E. M. Lanthaler \& R. Meraner (Eds.), Neue Lernkultur im Kindergarten und Schule (s. 46-62). Bozen: Pädagogisches Institut.

\section{Autor}

Doc. PhDr. Tomáš Janík, Ph.D., M.Ed., Masarykova univerzita, Pedagogická fakulta, Institut výzkumu školního vzdělávání, Poříčí 31, 60300 Brno, e-mail: tjanik@ped.muni.cz 


\title{
From curricular reform towards productive culture of teaching and learning
}

\begin{abstract}
The paper presents an analytical study that is concluded with an intended agenda setting. The "issue" of Czech curricular reform is defined on the theoretical level and analysed on the empirical level; moreover, its relationship to the culture of teaching and learning is described. At first, the current Czech curricular reform is viewed from the perspective of a broader context of educational transformation; its focus and character are discussed. The timing of the reform is addressed, using the equalizer of governance, i.e. an analysis of broader mechanisms of functioning of and operating the educational system. Central to the paper is the author's claim that the reform can hardly improve the quality of teaching and learning as its implementation resulted in unmanageable formalism. The author asserts that the quality can only be improved through sustained support of the productive culture of teaching and learning. To realise a change is thus to work on the new - productive - culture of teaching and learning. The study ends with an overview of arguments that confirm the need for an agenda setting that would aim at developing the curricular reform into a systematic approach to supporting schools and teachers' professional development which would take into account the idea of productive culture of teaching and learning.
\end{abstract}

Keywords: educational change, reform, curricular reform, educational transformation, curricular policy, culture of teaching and learning, teachers' professional development

Stráníková, J. (2013). Výchova a vzdělávání dívek na cestě k moderní občanské společnosti: genderové a sociální aspekty procesu socializace mládeže v období 1774-1868. Pardubice: Univerzita Pardubice.

Jak vypadalo dětství v 19. století? Jak rodiče vychovávali své děti? Jaká byla role otce a matky při výchově? Jaké byly požadavky pedagogů na výchovu dětí v rodině? Kde získávaly děti své vzdělání? Co očekávala společnost od školy? Jaké vzdělání poskytovala chlapcům a jaké dívkám? Jak vypadala výuka slohu? Jakou roli hrálo ve výchově náboženství? Jaká byla úroveň vzdělanosti žen v řemeslnických rodinách? Jak byly vzdělávány měštanské dívky z „lepších rodin“? Proč duchovním vadily negramotné ženy a proč pedagogové tolik volali po (přiměřeném) vzdělání žen? Tyto a mnohé další otázky si klade autorka této knihy. Odpovědi na ně hledala v dobové korespondenci, odborné literatuře i beletrii. 